\title{
Epidemiology of nosocomial bacteria resistant to antimicrobials
}

\author{
Cristina E. Cabrera, MSc ${ }^{1}$, Romel F. Gómez, BSc², Andrés E. Zuñiga, MSc², \\ Raúl H. Corral, MD, MSc ${ }^{1,2,3}$, Bertha López, MSc ${ }^{4}$, Mónica Chávez, $\mathrm{PhD}^{5}$
}

\section{SUMMARY}

Nosocomial infections are a major challenge for public health because of the high rates of morbidity and mortality generated. It was considered that the excessive or inappropriate use of antibiotics triggers the emergence of resistant strains. Among the clinically important bacteria that most commonly cause nososcomial infections, Gram positive multiresistant pathogens stand out such as methicillin-resistant Staphylococcus aureus (MRSA) and vancomycin-resistant Enterococcus spp (VRE), and the Gram negative strains of Klebsiella pneumoniae, Escherichia coli, Pseudomonas spp. and Acinetobacter baumannii producing expanded spectrum $\beta$-lactamases (ES $\beta \mathrm{L}$ ). This review describes the behavior of the main bacterial pathogens resistant to antibiotics that cause infections in Europe, United States, and Latin America, emphasizing studies of molecular epidemiology on a global scale, including the major epidemiological studies in Colombia. The genetic structure of S. aureus and Enterococcus spp strains shows a clonal characteristic favored by the predominance of a small number of clones with the capacity to spread globally, due probably to cross-infection. However, the introduction of MRSA strains from the community encourages genetic diversity, tending to establish a genetic polyclonal endemic structure in places like the United States. In Gram negative bacteria, the high genetic diversity among isolates, mainly in Latin American countries, indicates that the polyclonal spread is influenced by horizontal transfer of plasmids, by excessive exposure to antibiotics, and prolonged hospital stays. In Colombia, there is information on nosocomial resistant pathogens, but molecular epidemiological information is still scarce.

Keywords: Bacterial resistance; Antibiotics; Nosocomial infections; Epidemiology; Molecular epidemiology; Genetic diversity.

Colomb Med. 2011; 42: 117-25

Epidemiología de bacterias nosocomiales resistentes a los antimicrobianos

\section{RESUMEN}

Las infecciones nosocomiales constituyen un gran desafío para la salud pública por las altas tasas de morbilidad y mortalidad que generan. Se ha considerado que el uso inapropiado o excesivo de antibióticos desencadena la aparición de cepas resistentes. Entre las bacterias de importancia clínica que con mayor frecuencia causan infecciones nososcomiales, se destacan los patógenos Gram positivos multiresistentes como Staphylococcus aureus con resistencia a meticilina (SARM) y Enterococcus spp. resistentes a vancomicina (ERV). En los Gram negativos, hay resistencia sobre todo con las cepas de Klebsiella pneumoniae, Escherichia coli, Pseudomonas spp. y Acinetobacter baumannii productoras de $\beta$-lactamasas de espectro extendido (BLEEs, en inglés: ES $\beta$ L expanded spectrum $\beta$-lactamases). Esta revisión tiene como finalidad realizar una decripción del estado de la resistencia bacteriana a los antibióticos en los principales patógenos que causan infecciones nosocomiales en países de Europa, Estados Unidos y de Latinoamérica, destacando los estudios de epidemiología molecular

1. Assisting Professor, Area of Basic Sciences, Faculty of Health, Universidad Libre, Departament of Microbiology, Faculty of Health, Universidad del Valle, Cali, Colombia. e-mail: criseuca@gmail.com

2. Auxiliar Professor, Area of Basic Sciences, Faculty of Health, Universidad Libre, Cali, Colombia. e-mail: rofagom@gmail.com

3. Physician, Consorcio Universidad Libre-Comfenalco, Cali, Colombia. e-mail: raulhcorral@hotmail.com

4. Epidemiology Physician, Clínica de los Remedios, Cali, Colombia. e-mail: blope@hotmail.com

5. Research Professor, Area of Basic Sciences, Faculty of Health, Universidad Libre, Department of Biomedical Sciences, Universidad Santiago de Cali, Cali, Colombia. e-mail:: monikchavez@gmail.com

Received for publication February 12, 2010 Accepted for publication August 17, 2010 
a escala global e incluyendo los principales estudios epidemiológicos realizados en Colombia. La estructura genética de las cepas de Staphylococus aureus y Enterococcus spp. evidencia una característica clonal favorecida por el predominio de un número pequeño de clones con capacidad de diseminarse en forma global, debida probablemente a infecciones cruzadas. Sin embargo, la introducción de cepas SARM desde la comunidad está favoreciendo la diversidad genética, tendiendo a establecerse una estructura genética policlonal en lugares endémicos como los Estados Unidos. En las bacterias Gram negativas, se destaca una alta diversidad genética entre los aislados, sobre todo en países de Latinoamérica, indicando que la diseminación sigue una estructura genética policlonal, influida por la transferencia horizontal de plasmidos, por la excesiva exposición a antibióticos y una estancia hospitalaria prolongada. En Colombia se dispone de información sobre los patógenos nosocomiales resistentes, pero la información epidemiológica molecular aún es escasa.

Palabras clave: Resistencia bacteriana a antibióticos; Antibióticos; Infecciones nosocomiales; Epidemiología; Epidemiología molecular; Diversidad genética.

\section{Colomb Med. 2011; 42: 117-25}

Currently, studies on epidemiology surveillance report increased bacterial resistance to antimicrobial agents and their association with nosocomial infection, contributing to greater morbidity and mortality rates ${ }^{1}$. The nosocomial pathogens reported with the highest rates of resistance correspond to Gram-positive organisms like methicillin-resistant Staphylococcus aureus (MRSA). When vancomycin was introduced, the MRSA strains acquired resistance to this antibiotic, now denominated Vancomycin-Resistant Staphyloccocus aureus ${ }^{2}$ (VRSA). Coinciding with this circumstance, the first strains of vancomycin-resistant Enterococcus spp. (VRE) appeared; now widely distributed worldwide ${ }^{3}$.

In Gram-negative bacilli, resistance is given mainly by $\beta$-lactamase enzimes classified into two important groups: expanded spectrum $\beta$-lactamases (ES $\beta \mathrm{L}$ ), codified in megaplasmids, and the inducible chromosomal $\beta$-lactamase ${ }^{4}$. The strains with ES $\beta$ Ls are reported mainly in Klebsiella pneumoniae, Escherichia coli, Proteus mirabilis, and other species like Enterobacter sp. and Citrobacter freundii, becoming an important health problem, which has rapidly increased and spread throughout the world ${ }^{5}$. Moreover, chromosomal $\beta$-lactamase is described in nonfementing Gram-negative bacilli like Citrobacter spp., Enterobacter spp., Serratia spp., Providencia spp., Pseudomonas spp., and Acinetobacter baumannii. These bacteria are grouped under the acronym SPACE (S: Serratia; P: Pseudomonas; A: Acinetobacter; C: Citrobacter; E: Enterobacter). The greatest state of resistance in this group is principally reported in multidrug-resistant Pseudomonas aeruginosa and Acinetobacter spp. (MDRs) $)^{5,6}$.

The state of world resistance of nosocomial pathogens, and of those appearing in community, is monitored by different surveillance programs, among which is the SENTRY program incorporating molecular typification of strains and the genotypification of the resistance as a mechanism of additional information, which permits following the world distribution of pathogenic microorganisms, within the denominated molecular epidemiology. Some of the molecular techniques used in this type of analysis include: ribotyping, genomic analysis of the amplified fragment length polymorphism (AFLP), pulsed field gel electrophoresis (PFGE), random amplification of polymorphic DNA (RAPD), arbitrary primed polymerase chain reaction (AP-PCR), amplification of repetitive element sequence-based PCR (rep-PCR), and multilocus sequence typification (MLST) ${ }^{7}$.

This review will address epidemiological studies reporting the state of antimicrobial resistance in nosocomial pathogens in developed nations like the United States and some European nations, in contrast with Latin American nations including Colombia.

State of antimicrobial resistance in the world. Worldwide, the state of resistance increased considerably in Gram-positive and Gram-negative pathogens. Reports indicate that among Gram-positive organisms $S$. aureus is one of the pathogens with the tendency to more quickly acquire resistance. This bacterium whose resistance has reached worldwide epidemic proportions, is naturally susceptible to most antibiotics developed. Resistance is often acquired by horizontal transfer of external origin genes, chromosomal mutation, and antibiotic selection. Most diseases produced by this bacterium are caused by MRSA strains, which have been on the rise in many countries both at the community level and hospitals ${ }^{2}$. 
In England, there are reports of increased proportion of MRSA isolates since 1990 at $2 \%$, reaching its maximum peak at $43 \%$ in $2002^{8}$. In spite of the contention measures taken to diminish spread of the pathogen, by the end of 2010, MRSA epidemic outbreaks continue to be reported ${ }^{9}$. The epidemiological state of MRSA in other European nations registers similar behavior. In Spain, the MRSA strains have presented a notable increase in nosocomial infections in recent years ${ }^{10}$. However, in other countries the measures to control the spread of MRSA strains have had a positive effect; thus, for example, Denmark reports cases of MRSA infections since the 1970s, mortality in cases of bacteremia diminished notably until the year $2000^{11}$.

In Asian nations like Japan, cases of patients developing infections through MRSA were 35.8\% during the start of the decade of $2000^{12}$. According to epidemiological studies, in the United States the MRSA strains presented a $32.4 \%$ rate of occurrence during 1997 and $2002^{13}$. For 2004 and 2005, the prevalence increased dramatically, favored by the spread of the strains in the community ${ }^{14}$.

For other Gram-positive bacteria, epidemiological surveillance systems indicate that the recurrence and spread of antibiotic resistant Enterococcus present differences between geographic areas ${ }^{3}$. According to the 2002 annual report by the European surveillance system (http//:www.earss.rivm.nl), the prevalence of ampicillin-resistant Enterococcus faecium strains reached rates up to $10 \%$ in six European countries. This increase was even greater in some countries like Denmark $^{15}$. Nevertheless, the epidemiological pattern changed during the last eight years, when resistance to vancomycin became evident in some ampicillin-resistant Enterococcus strains ${ }^{3}$. Resistance to vancomycin is mainly determined by the acquisition of transposons, with high power to spread among strains with different genetic determinants ${ }^{16}$. For the first decade of 2000, a high occurrence rate of VRE infections was registered in countries like Spain ${ }^{17}$.

In Asia, the VRE strains have been isolated from patients hospitalized and from the community, mainly in countries like Japan ${ }^{18}$ and South Korea ${ }^{19}$. The introduction of the pathogen into the community was primarily due to the consumption of contaminated meats ${ }^{18,19}$. In the United States, as in Europe, public health problems generated by Enterococcus are influenced by the recurrence of vancomycin-resistant nosocomial Enterococcus faecium outbreaks during the decade of $2000^{3}$. Epidemiological reports of Gramnegative bacteria point to bacteria from the family of ES $\beta$ L-producing Enteobacteriaceae, as the main generators of nosocomial infections ${ }^{4}$.

An important presence of ES $\beta \mathrm{L}$ producing $K$. pneumoniae strains was reported in Southern and Western Europe during the late $1990^{\prime} \mathrm{s}^{20}$. The presence of these strains is still being reported during this decade in hospital wards in Italy ${ }^{21}$. In Spain, epidemiological records reveal that the participation of ES $\beta$ L producing strains has been maintained in nosocomial infections; but with a preoccupying extension to the community ${ }^{22}$. The presence of these strains in the community is reported in other countries like Poland, France, and the United Kingdom, among others ${ }^{23}$.

The epidemiological behavior of ES $\beta$ L producing $K$. pneumoniae has generated serious public health problems in Asian nations like China ${ }^{24}$, in African nations ${ }^{25}$, and in the American continent, especially in the United States ${ }^{26}$.

Ever since the determination of the presence of ES $\beta$ Ls for the first time in E.coli strains in Europe, the frequency of these strains transporting these resistance determinants has been kept high, as indicated by epidemiological reports in Spain ${ }^{27}$ and France ${ }^{28}$.

In the United States, during the last decade, the presence of ES $\beta$ L producing $E$. coli strains in hospitals in different states ${ }^{29}$, with a preoccupying increase in the community $^{30}$.

When studying the epidemiological behavior of nonfementing enterobacteria, we found that the situation worsens and particularly with $A$. baumannii because this pathogen plays an important function in colonization and infection of patients, especially those Intensive Care Units (ICU) of hospitals worldwide ${ }^{31,32}$.

Effective treatment against infections caused by $A$. baumannii was via carbapenem; however, resistance to this class of $\beta$-lactam antibiotic is now habitual ${ }^{31}$. Similar results were obtained with the use of other potentially effective antibiotics against $A$. baumannii like tetracyclines, last generation aminoglycosides, and sulbactam $^{32}$.

The emergence of strains simultaneously resistant to three drugs, introduced the epidemiological term of multiresistance and resistance to all panresistance ${ }^{31-33}$. 
The presence of multiresistant strains in some European and Asian nations constitutes a serious public health problem ${ }^{34}$; the situation turns more alarming with the emergence of multiresistant and panresistant $A$. baumannii strains ${ }^{31,33}$.

Multiresistant strains often spread and cause epidemic outbreaks in entire cities, countries, and continents ${ }^{34}$. The exchange of multiresistant strains between continents has been demonstrated, as evidenced by a study on molecular epidemiology, which determined the presence of multiresistant $A$. baumannii clones in hospitals in the United States and Europe, but with different genetic determinants ${ }^{35}$. Nonetheless, the existence of identical clones has been identified in military and civilian personnel from the United States and the United Kingdom who had returned from operations in Afganistan and Irak ${ }^{36,37}$.

Antimicrobian resistance in nosocomial pathogens in the world reveals greater prevalence of Gram-positive bacteria in Europe, especially MRSA strains. In contrast, the United States presents similarities in the presence of Staphylococcus spp., Enterococcus spp., and nonfementing Gram-negative organisms. These results show the need for implementing government policies in integral health, which permit a better quality of life, involve nutritional conditions, adequate administration of wastes and of chemotherapeuticals, as applied in several European countries in recent years.

State of resistance in Latin America. The first reports of resistance in nosocomial infections were made in Argentina and Brazil in the late $1990 \mathrm{~s}^{38}$. Reports in Latin America indicate that MRSA strains bear epidemiological importance in Mexican hospitals, as revealed by epidemiological studies conducted from 1997 to $2003^{39}$ and in Venezuela in 2005, where the MRSA strains also signaled resistance to oxacilin, gentamicin, erythromycin, and tobramycin and in $93 \%$ of the cases it was due to the presence of the mecA gene $^{40}$. In Asunción, Paraguay, the prevalence of MRSA strains corresponded to $43.8 \%{ }^{41}$ and in several cities in Argentina, especially in Córdoba with a $37 \%$ prevalence ${ }^{42}$.

In spite of the great epidemiological relevance of $S$. aureus in Latin American nations, cases of infection due to VRE are reported in hospitals in Argentina ${ }^{43}$, Chile $^{44}$, and Perú ${ }^{45}$. Among Gram-positive bacteria, those most frequently reported causing nosocomial infections correspond to ES $\beta$ L producing $E$. coli in Chile, Argentina, Brazil ${ }^{46}$, Perú, and Bolivia ${ }^{47}$. The $K$. pneumoniae strains turned out to be ESBL producing by $27.6 \%$ in Mexico and by $47.5 \%$ in Brazil ${ }^{46}$. In Chile, it is reported that poor use of antibiotics like ceftriaxone was important in promoting the spread of ES $\beta \mathrm{L}$ producing $K$. pneumoniae strains ${ }^{48}$.

The presence of multiresistant $A$. baumannii has generated serious public health problems with reports of epidemic outbreaks in hospitals in Argentina ${ }^{49}$ and, according to SENTRY, in hospitals of Brazil, Chile, and Uruguay ${ }^{50}$, among other countries.

The principal studies on resistance of nosocomial bacteria have been conducted in Argentina, Brazil, and Chile. According to reports, it was observed that the highest resistance rates among MRSA strains exist in Venezuela, while for Argentina, Brazil, México, Perú, and Bolivia resistance is most alarmingly registered in the Enterobacteriaceae family, with a special tendency in the propagation of A. baumannii. However, there is a lower distribution in resistance measured for ES $\beta$ Ls in southern cone Latin American nations, especially enteropathogens like E. coli and $K$. pneumoniae. In contrast, we observed greater resistance tendency in countries like México and Brazil for these same pathogens. For Enterobacter spp. a tendency to diminished resistance was observed in recent years, primarily in Southern hemisphere nations.

State of resistance in Colombia. Epidemiological studies conducted in Bogotá by Álvarez et al. ${ }^{51}$, in early 2000 reveal predominance of bacteria from the Enterobacteriaceae family, with a $34 \%$ prevalence for $K$. pneumoniae, $37 \%$ for $P$. aeruginosa, and $38 \%$ for $A$. baumannii, these last are imipenem resistant. In another study conducted in 2002 and 2003, the most frequent nosocomial microorganisms corresponded to $S$. aureus at $24 \%, E$. coli at $18 \%, P$. aeruginosa at $9 \%, A$. baumannii at $6 \%{ }^{52}$. A molecular epidemiology study of ESBL producing strains determined the significant presence of $K$. pneumoniae ${ }^{53}$, with the prevalence of a unique clone in hospitals in different cities ${ }^{54}$.

In 2006, a molecular study was conducted on metalo$\beta$-lactamase ( $\mathrm{M} \beta \mathrm{L}$ ) producing $A$. baumannii strains in clinical isolates in Intensive Care Units at hospitals in Bogotá $^{55}$. The data obtained by the CIDEIM group in 2004, including several hospitals in Colombia, report the presence of imipenem-resistant $A$. baumannii and 
P. aeruginosa ${ }^{56}$.

Among the resistance observed in the Gram-positive cocci, the MRSA strains showed resistance rates between $24 \%$ and $48 \%$ in studies carried out in hospitals of Bogotá ${ }^{57}$; these data are similar to those recorded in Paraguay with a predominant clone. Data reported for VRE revealed low prevalence. Toward more populated zones in our country, we observed a high percentage of resistance in ES $\beta$ L producing Gram-negative bacteria. For Enterobacter spp. strains, we observed a greater rate of resistance in cities in the Atlantic Coast. In the Andean region and in the Atlantic Coast, we noted a high percentage of resistance in bacteria like $P$. aeruginosa and A. baumannii.

Molecular epidemiology of nosocomial bacteria. Global epidemiology of the state of resistance in nosocomial bacteria is variable and it is very much related to policies in each nation. Thus, for example, when analyzing the genetic structure of the Enterococcus spp. resistant population the greatest prevalence is registered in the United States, reaching endemic situations with clonal dispersion ${ }^{3}$. However, this characteristic has changed in recent years, favored by the introduction of endemic strains from the community onto the hospital environment with new resistance determinants, generating a polyclonal dispersion tendency as observed in Europa ${ }^{17}$. Although the incidence rate of VRE infection at the intrahospital level is low, the high frequency of colonization at the community level is perhaps favored by the introduction of resistant strains through the consumption of farm animals as evidenced by some rerorts ${ }^{18,19}$.

In the analysis of the VRE world population structure were identified 55 sequence types (ST) with 4 clonal complexes (CC2, CC9, CC10, CC21); complexes denominated CC2 and CC9 are the most frequent and circulate primarily in Central Europe and America ${ }^{3,17}$.

For MRSA strains, large-scale population genetics studies published in 1999 and 2000, identified five clonal complexes or pandemics: Iberian Clone, Brazilian Clone, Hungarian Clone, New York/Japan Clone, and Pediatric Clone ${ }^{58}$.

Current epidemiological studies have demonstrated that the pediatric clone is the most frequent with resistance to $\beta$-lactam antibiotics; this clone has been identified in isolates from Poland, the United States, Argentina, and Colombia. Some researchers suggest that because of their stability over time and their great power to spread throughout the continents it may be the oldest MRSA clone ${ }^{59}$. The second clone with great power to spread is the Iberian clone found in isolates from several European countries, mainly Portugal, Spain, as well as the United States, where it has been identified in New York city hospitals ${ }^{14}$. The New York/ Japan clone is highly predominant in Asian nations ${ }^{12}$.

The first molecular work to determine MRSA clones in Latin America was done in 2001, finding that the Brazilian clone was present in $79 \%$ of the strains in Argentina, Chile, and Uruguay ${ }^{38}$. In Brazil, intrahospital infections caused by Staphylococcus spp corresponded to $80 \%$ to $90 \%$ through MRSA and all the strains with the Brazilian clone profile. The pediatric clone was detected in Paraguay ${ }^{41}$, Argentina ${ }^{42}$, Chile ${ }^{46}$, and Colombia ${ }^{57}$. México registered strains sharing the New York clone profile and a group of strains with a unique diversity classified as $\mathrm{M}$ clone ${ }^{39}$.

Disemination of an MRSA resistant clone among Latin America countries including Chile, Paraguay, Argentina, and Brazil was detected in the late $1990 \mathrm{~s}^{38}$. It was, thereafter, confirmed by studies conducted by Sader et al. ${ }^{46}$, in 2000.

The population genetics study of Gram-negative bacteria with ES $\beta$ Ls shows a high diversity, as with $K$. pneumoniae and $E$. coli strains ${ }^{21,22,26-28}$. Some studies reveal clonal dispersion for the population of $K$. pneumoniae and $E$. coli ${ }^{26,27}$. The study conducted by Deshpande et al. ${ }^{60}$ in 2004 determined that the ribotypes identified in the ES $\beta \mathrm{L}$ producing strains from Europe, the United States, and Latin America were restricted to one continent or to one country in particular, except for a clone from the United States and Europe with a shared pattern. Pattern similar results were obtained from analysis done on MDR K. pneumoniae strains isolated from epidemic outbreaks in different hospitals in European countries, the data reveal great variability in the resistance patterns, but they all belonged to the same clone $^{21}$. The variation was because the resistance measured via diverse mechanisms like: integrons transporting the a adB gene (which confers resistance to gentamicin); in other strains because of the presence of the aadA gene (which confers resistance to streptomycin), or to the presence of both genes in a trans$\operatorname{poson}^{5,24,25}$. In all the strains analyzed, a mutation was determined in the gyrA gene, which confers resistance 
to ciprofloxacin and the presence of the SHV-5 gene in the resistance mediated by ES $\beta \mathrm{Ls}^{61}$.

In the population structure of the $E$. coli strains, we noted similar behavior to $K$. pneumoniae. We found that the $\beta$-lactamase producing $E$. coli strains in hospitals in Paris was a clone that was primarily spread, according to findings in a hospital in Tunisia and in the Central African Republic $^{28}$. Researchers suggest that the spread was probably due to characteristic of the clone, with an extraordinary tendency to colonizing or via horizontal transfer of plasmids on mosaics transporting the resistance gene ${ }^{28}$.

In Latin America, there are studies of E. coli population genetics in Brazil conducted by MartinsLoureiro et al. ${ }^{62}$, in 2001, who found 6 clones in a group of 42 epidemiologically related strains, with 9 PFGE profiles of resistance to the antimicrobial (A-I). The most frequent clones were: A with 5 profiles, B with 3 profiles and $\mathrm{D}$ with 5 profiles. According to the profiles and to the isolation periods, clones $\mathrm{A}, \mathrm{A} 1, \mathrm{~B}$, and $\mathrm{D}$ caused three outbreaks during the study period.

In Colombia, molecular epidemiology studies have evidenced similar behavior to that registered in the rest of the Latin American nations; thus, for example, the molecular characterization of $K$. pneumoniae with ES $\beta$ Ls obtained from patients in a third-level hospital in Bogotá revealed that the genetic variability was related to nosocomial infections of endogenous origin rather than cross infections ${ }^{53,54}$. In this analysis, the isolates were grouped by PFGE and REP-PCR into 11 and 12 electrophoretic patterns, respectively ${ }^{54}$. In studies published by Espinal et al. ${ }^{53}$, in 2004, it was shown that all $K$. pneumoniae isolates were ES $\beta \mathrm{L}$ producers and the genotyping by PFGE and BOX-PCR grouped two isolates from hospital environments, as well as eight isolates that caused infection in an epidemic clonal group. The isolate from a thermometer was not associated to the epidemic clonal group and revealed a different resistance pattern.

The estate of molecular epidemiology of nonfermenting pathogens shows increased prevalence of infections due to resistant strains. In the United States, the most frequent $P$. aeruginosa and $A$. baumannii clonal outbreaks have been detected in cities like New York with a ribotype identical to one reported in Spain, but with a different PFGE pattern ${ }^{35}$. Likewise, common clones have been identified in isolates from the United States and the United Kingdom ${ }^{36,37}$. These studies demonstrate that in Latin American nations, the resistance pattern is more widespread, with MDR strains predominating as principal etiological agents for nosocomial infection that are gaining importance in community-type infections $s^{49,50,55}$.

Regarding the population structure of A. baumannii, there are important studies like those conducted in European hospitals during the early part of the 2000 decade, which identified a great diversity of clones specifically resistant to polimyxin $\beta$, aminocycline, imipenem, rifampin, sulbactam, meropenem, amikacin, and doxycycline ${ }^{34}$. In Latin American countries, the most important studies on this pathogen are reported in Argentina where it has been determined that $A$. baumannii strains resistant to carbapenems with shared profile with a clone isolated in Israel ${ }^{49}$.

In studies carried out in Colombia, much work was done on molecular characterization during 2003 and 2004 in nosocomial isolates among which there is $A$. baumannii, which caused an epidemic outbreak in a hospital in Bogotá and the determination of associated factors. In this study, it was determined that the isolates were resistant to multiple antibiotics and were genetically related with a similarity percentage greater than $97 \%{ }^{52}$. In studies done by Pinzón et al. ${ }^{55}$, in 2006 , 9 (A-1) groups were identified; the E group was made up of $39.2 \%$ of the isolates and a clone comprising three environmental isolates and two recovered from patients.

Molecular epidemiology studies on Gram-positive pathogens evidence the predominance of a small number of clones responsible for Staphylococcal infection throughout the world, i.e., they are able to diseminate globally (pandemic MRSA clones), probably favored by cross infections with strains closely related among hospitals and distant locations.

In Gram-negative bacteria, the high genetic diversity among the isolates of the enterobacteria, primarily in Latin American countries, indicates that disemination is polyclonal in the hospital environment, influenced by the horizontal transference of plasmids among different strains, which are under high selective pressure by broad-spectrum antibiotics. For fermenting enterobacteria with resistance mediated by ES $\beta$ Ls, polyclonaltype dispersion is established characterized by high genetic diversity, perhaps associated to the selection of resistant organisms caused by excessive exposure to antibiotics and prolonged hospital stays. 


\section{PERSPECTIVES}

In Latin America, bacterial resistance in hospitals presents a high variety with small differences among countries, including Colombia. Nevertheless, molecular epidemiology studies conducted until now in the country have been limited to some regions; it is necessary to carry out a nationwide population genetics study integrating nosocomial pathogens from different places, including greater impact Gram-positive organisms like MRSA strains, and among the Gram-negative organisms, fermenting enteric bacteria like $K$. pneumoniae and $E$. coli, and non-fermenting bacteria, especially $A$. baumannii, which has currently become a serious morbidity and mortality problem in the country. It is necessary to determine if the microorganism follows a behavior similar to that observed in other Latin American nations and its genetic relationship with strains circulating in other regions of the world.

The use of molecular epidemiology in the study of nosocomial infections has been fundamental for the formulation and evaluation of control measures, for the purpose of diminishing the propagation of resistant clones. With this strategy, we are able to determine the factors contributing to the epidemic superiority of the clones, the surpisingly high level of expression of certain virulence genes, and their survival ability in the environment. These factors are important in adopting measures to control the dispersion of resistant pathogens and avoid the emergence of strains with greater degrees of resistance and pathogenicity.

\section{REFERENCES}

1. Jones RN. Pathogens: Trends over the past few years resistance patterns among nosocomial. Chest. 2001; 119: 397-404.

2. Chambers HF, DeLeo FR. Waves of resistance: Staphylococcus aureus in the antibiotic era. Nat Rev Microbiol. 2009; 7: 62941.

3. Leavis HL, Bonten MJ, Willems RJ. Identification of highrisk enterococcal clonal complexes: global dispersion and antibiotic resistance. Curr Opin Microbiol. 2006; 9: 454-60.

4. Schwaber MJ, Navon-Venezia S, Schwartz D, Carmeli Y. High levels of antimicrobial coresistance among extendedspectrum- $\alpha$-lactamase-producing Enterobacteriaceae. Antimicrob. Agents Chemother. 2005; 49: 2137-9.

5. Thomson KS, Smith ME. The new $\alpha$-lactamases of Gramnegative bacteria at the dawn of the new millennium. Microb Infect. 2000; 2: 1225-35.

6. Riccio ML, Franceschini N, Boschi L, Caravelli B, Cornaglia
G, Fontana R, et al. Characterization of the metallo- $\alpha$-lactamase determinant of Acinetobacter baumannii AC-54/97 reveals the existence of bla (IMP) allelic variants carried by gene cassettes of different phylogeny. Antimicrob Agents Chemother. 2000; 44: 1229-35.

7. Fluit ADC, Visser MR, Schmitz FJ. Molecular detection of antimicrobial resistance. Clin Microbiol Rev. 2001; 14: 83671.

8. Johnson AP, Duckworth G, Pearson A. Surveillance and epidemiology of MRSA bacteraemia in the UK. J Antimicrob Chemother. 2005; 56: 455-62.

9. Pearson A, Chronias A, Murria M. Voluntary and mandatory surveillance for methicillin-resistant Staphylococcus aureus (MRSA) and methicillin-susceptible S. aureus (MSSA) bacteraemia in England. J Antimicrob Chemother. 2009; 64 (Supl 1): i11-i17.

10. Argudín MA, Mendoza MC, Méndez FJ, Martín MC, Guerra B, Rodicio MR. Clonal complexes and diversity of exotoxin gene profiles in methicillin-resistant and methicillin-susceptible Staphylococcus aureus isolates from patients in a Spanish hospital. J Clin Microbiol. 2009; 47: 2097-105.

11. Benfield T, Espersen F, Frimodt-Moller N, Jensen AG, Larsen AR, Pallesen LV, et al. Increasing incidence but decreasing in-hospital mortality of adult Staphylococcus aureus bacteraemia between 1981 and 2000. Clin Microbiol Infect. 2007; 13: 257-63.

12. Benquan W, Yingchun T, Kouxing Z, Tiantuo Z, Jiaxing Z, Shuqing T. Staphylococcus heterogeneously resistant to vancomycin in China and antimicrobial activities of imipenem and vancomycin in combination against It. J Clin Microbiol. 2002; 40: 1109-12.

13. Biedenbach DJ, Moet GJ, Jones RN. Occurrence and antimicrobial resistance pattern comparisons among bloodstream infection isolate from de SENTRY antimicrobial survillence programs (1997-2002). Diagn Microbiol Infect Dis. 2004; 50: 59-69.

14. Kennedy AD, Otto M, Braughton KR, Whitney AR, Chen L, Mathema B, et al. Epidemic community-associated methicillinresistant Staphylococcus aureus: Recent clonal expansionand diversification. Proc Natl Acad Sci USA. 2008; 105: 1327-32.

15. Lester CH, Sandvang D, Olsen SS, Schonheyder HC, Jarlov JO, Bangsborg J. Emergence of ampicillin-resistant Enterococcus faecium in Danish hospitals. J Antimicrob Chemother. 2008; 62: 1203-6.

16. Schouten MA, Willems RJL, Kraak WAG, Top J, HoogkampKorstanje JAA, Voss A. Molecular analysis of Tn1546-like elements in vancomycin-resistant enterococci isolated from patients in Europe shows geographic transposon type clustering. Antimicrob Agents Chemother. 2001; 45: 986-9.

17. Coque TM, Willems RJ, Fortun J, Top J, Diz S, Loza E, et al. Population structure of Enterococcus faecium causing bacteremia in a spanish university hospital: setting the scene for a future increase in vancomycin resistance? Antimicrob Agents Chemother. 2005; 49: 2693-700.

18. Ozawa Y, Tanimoto K, Nomura T, Yoshinaga M, Arakawam Y, Ike Y. Vancomycin-resistant enterococci in humans and imported chickensin Japan. Appl Environ Microbiol. 2002; 
68: 6457-61.

19. Yu HS, Seol SY, Cho DT. Diversity of Tn1546-like elements in vancomycin-resistant enterococci isolated from humans and poultry in Korea. J Clin Microbiol. 2003; 41: 2641-3.

20. Babini GS, Livermore DM. Antimicrobial resistance amongs Klebsiella spp. colleted from intensive care units in Southern and Western Europe in 1997-1998. J Antimicrob Chemother. 2000; 45: 183-9.

21. Bagattini M, Crivaro V, Di Popolo A, Gentile F, Scarcella A, Triassi M, et al. Molecular epidemiology of extended-spectrum $\alpha$-lactamase-producing Klebsiella pneumoniae in a neonatal intensive care unit. J Antimicrob Chemother. 2006; 57: 97982.

22. Valverde A, Coque TM, García-San Miguel L, Baquero F, Canto R. Complex molecular epidemiology of extendedspectrum $\alpha$-lactamases in Klebsiella pneumoniae: a long-term perspective from a single institution in Madrid. J Antimicrob Chemother. 2008; 61: 64-72.

23. Livermore DM, Canton R, Gniadkowsk M, Nordmann P, Rossolini GM, Arlet G, et al. CTX-M: changing the face of ES $\beta$ Ls in Europe. J Antimicrob Chemother. 2007; 59: 165-74.

24. Wei ZQ, Du XX, Yu YS, Shen P, Chen YG, Li LJ. Plasmidmediated KPC-2 in a Klebsiella pneumoniae isolate from China. Antimicrob Agents Chemother. 2007; 51: 763-76.

25. Gangoue-Pieboji J, Miriagou V, Vourli S, Tzelepi E, Ngassam $\mathrm{P}$, Tzouvelekis LS. Emergence of CTX-M-15-producing enterobacteria in Cameroon and characterization of a blaCTXM-15-carrying element. Antimicrob Agents Chemother. 2005; 49: 441-3.

26. Kitchel B, Rasheed K, Patel JB, Srinivasan A, Navon-Venezia $\mathrm{S}$, Carmeli Y, et al. Molecular epidemiology of KPC-producing Klebsiella pneumoniae isolates in the United States: clonal expansion of multilocus sequence type 258. Antimicrob Agents Chemother. 2009; 53: 3365-70.

27. Blanco M, Alonso MP, Nicolas-Chanoine MH, Dahbi G, Mora A, Blanco JE, et al. Molecular epidemiology of Escherichia coli producing extended-spectrum $\alpha$-lactamases in Lugo (Spain): dissemination of clone O25b:H4-ST131 producing CTX-M-15. J Antimicrob Chemother. 2009; 63: 1135-41.

28. Lavollay M, Mamlouk K, Frank T, Akpabie A, Burghoffer B, Redjeb S, et al. Clonal dissemination of a CTX-M-15- $\beta$ lactamase-producing Escherichia coli strain in the Paris area, Tunis, and Bangui. Antimicrob Agents Chemether. 2006; 50: 2433-8.

29. Smith ME, Black JA, Hossain A, Hanson ND, Thomson KS, Pottumarthy S. Discovery of CTX-M-like extended-spectrum $\alpha$-lactamases in Escherichia coli isolates from five US States. Antimicrob Agents Chemother. 2003; 47: 2382-3.

30. Pitout JDD, Nordmann P, Laupland KB, Poirel L. Emergence of Enterobacteriaceae-producing extended-spectrum $\beta$ lactamases (ES $\beta$ Ls) in the community. J Antimicrob Chemother. 2005; 56: 52-9.

31. Hsueh PR, Teng LJ, Chen CY, Chen WH, Yu CJ, Ho SW, et al. Pandrug-resistant Acinetobacter baumannii causing nosocomial infections in a university hospital, Taiwan. Emerg Infect Dis. 2002; 8: 827-32.

32. Rice LB. Challenges in identifying new antimicrobial agents effective for treating infections with Acinetobacter baumannii and Pseudomonas aeruginosa. Clin Infect Dis. 2006; 43 (Suppl 2): S100-5.

33. Houang ET, Chu YW, Leung CM, Chu KY, Berlau J, Ng KC, et al. Epidemiology and infection control implications of Acinetobacter spp. in Hong Kong. J Clin Microbiol. 2001; 39: 228-34.

34. Van Dessel H, Dijkshoorn L, van der Reijden T, Bakker N, Paauw A, van den Broek $\mathrm{P}$, et al. Identification of a new geographically widespread multiresistant Acinetobacter baumannii clone from European hospitals. Res Microbiol. 2004; 155: 105-12.

35. Quale J, Bratu S, Landman D, Heddurshetti R. Molecular epidemiology and mechanisms of carbapenem resistance in Acinetobacter baumannii endemic in New York City. Clin Infect Dis. 2003; 37: 214-20.

36. Jones A, Morgan D, Walsh A, Turton J, Livermore D, Pitt T, et al. Importation of multidrug-resistant Acinetobacter spp. infections with casualties from Iraq. Lancet Infect Dis. 2006; 6: 317-8.

37. Turton JF, Kaufmann ME, Gill MJ, Pike R, Scott PT, Fishbain $\mathrm{J}$, et al. Comparison of Acinetobacter baumannii isolates from the United Kingdom and the United States that were associated with repatriated casualties of the Iraq conflict. JClin Microbiol. 2006; 44: 2630-4.

38. Aires De Sousa M, Miragaia M, Santos I, Avila S, Adamson I, Casagrande S, et al. Three year assesment of methicillinresistant Sthaphyloccus aureus clones in Latin America from 1996 to 1998. J Clin Microbiol. 2001; 39: 2197-205.

39. Velázquez MME, Aires de Sousa M, Echaniz AG, Solorzano SF, Miranda NG, Silva SJ, et al. Surveillance of methicillinresistant Staphylococcus aureus in a pediatric hospital in Mexico City during a 7-year period (1997 to 2003): Clonal evolution and impact of infection control. J Clin Microbiol. 2004; 42: 3877-80.

40. Velazco E, Nieves B, Araque M, Calderas Z. Epidemiología de Staphylococcus aureus en una unidad de alto riesgo neonatal. Enferm Infecc Microbiol Clin. 2002; 20: 321-5.

41. Mayor L, Ortellado J, Menacho C, Lird G, Courtier C, Gardon $\mathrm{C}$, et al. Molecular characterization of methicillin-resistant Staphylococcus aureus isolates collected in Asunción, Paraguay. J Clin Microbiol. 2007; 45: 2298-300.

42. Sola C, Cortés P, Saka HA, Córdoba MRSA Collaborative Study Group, Vindel A, Bocco JL. Evolution and molecular characterization of methicillin-resistant Staphylococcus aureus epidemic and sporadic clones in Cordoba, Argentina. J Clin Microbiol. 2006. 44: 192-200.

43. Ponessa A, Gambande T, All L. Enterococos vancomicina resistentes: colonización en pacientes hospitalizados, en Rosario, Argentina. Acta Bioquim Clin Latinoam. 2006; 40: 499502.

44. Marovac J, Campos MI. Enterococcus faecium resistente a vancomicina. Rev Med Chile. 2000; 128: 685-6.

45. Velásquez J, Lizaraso F, Zetola N, Pamno O, Sánchez L, Wong W, et al. Vigilancia de la resistencia de enterococcus sp a la vigilancia y evaluacion in vitro de nuevas alternativas terapéuticas. Rev Soc Peru Med Int. 2002; 15: 1-5.

46. Sader HS, Gales AC, Casellas JM, Smayevsky J, Prado V, 
Palaveccino E, et al. Comparison of the antimicrobial susceptibilities of nosocomial bacteria among Latin American countries. Intersci Conf Antimicrob Agents Chemother. 2000; 20: 40-85.

47. Pallecchi L, Malossi M, Mantella A, Gotuzzo E, Trigoso C, Bartoloni A, et al. Detection of CTX-Mtype $\alpha$-lactamase genes in fecal Escherichia coli from healthy children in Bolivia and Peru. Antimicrob Agents Chemother. 2004; 48: 4556-61.

48. Díaz P, Bello H, Domínguez M, Trabal N, Mella S, Zemelman $\mathrm{R}$, et al. Resistencia a gentamicina, amikacina y ciprofloxacina en cepas hospitalarias de Klebsiella pneumoniae subespecie pneumoniae productoras de $\alpha$-lactamasas de espectro extendido. Rev Med Chile. 2004; 132: 1173-8.

49. Barbolla RE, Centron D, Di Martino A, Maimone S, Salgueira C, Famiglietti A. Identification of an epidemic carbapenemresistant Acinetobacter baumannii strain at hospitals in Buenos Aires City. Diag Microbiol Infect Dis. 2003; 45: 261-4.

50. Sader HS, Jones RN, Gales AC, SilvaJB, Pignatari AC. SENTRY antimicrobial surveillance program report: Latin America and Brazilian results for 1997 through 2001. Braz J Infect Dis. 2004; 8: 25-79.

51. Álvarez C, Cortés J, Arango A, Correa C, Leal A, GREBO. Resistencia antimicrobiana en unidades de cuidado intensivo de Bogotá, Colombia, 2001-2003. Revista de Salud Pública [en línea] 2006, 8: [fecha de consulta: 12 de marzo de 2011] Disponible en: http://redalyc.uaemex.mx/redalyc/src/inicio/ ArtPdfRed.jsp?iCve=42289908

52. Leal AL, Eslava J, Álvarez C, Buitrago G, Méndez M, GREBO. Canales endémicos y marcadores de resistencia bacteriana, en instituciones de tercer nivel de Bogotá, Colombia. Revista de Salud Pública. 2006; 859-70. Disponible en: http://redalyc. uaemex.mx/redalyc/src/inicio/ArtPdfRed.jsp?iCve $=4228$ 9906

53. Espinal PA, Mantilla JR, Saavedra CH, Leal AL, Alpuche C, Valenzuela EM. Epidemiología molecular de infección nosocomial por Klebsiella pneumoniae productora de âlactamasas de espectro extendido. Biomedica. 2004; 24: 25261.

54. Mantilla JR, Valenzuela EM, Gil CA, Leal AL. Caracterización molecular de Klebsiella pneumoniae productora de $\beta$ lactamasas de espectro estendido ( $\beta$ LEE) del tipo CTM-X-12. Infectio. 2004; 8: 143.
55. Pinzón J, Mantilla JR, Valenzuela EM, Fernández F, Álvarez CA, Osorio E. Caracterización molecular de aislamientos de Acinetobacter baumannii provenientes de la unidad de quemados de un hospital de tercer nivel de Bogotá. Infectio. 2006; 10: 71-8.

56. Suárez CJ, Kattán JN, Guzmán AM, Villegas MV. Mecanismos de resistencia a carbapenems en $P$. aeruginosa, Acinetobacter y Enterobacteriaceae y estrategias para su prevención y control. Infectio. 2006; 10: 85-93.

57. Gómes AR, Sánches I, Aires De Sousa M, Castañeda E, De Lencastre H. Molecular epidemiology of methicillin-resistant Staphylococcus aureus in Colombian hospitals: Dominance of a single unique multidrug-resistant clone. Microb Drug Resist. 2001; 7: 23-32.

58. Enright MC, Robinson DA, Randle G, Feil EJ, Grundmann H, Spratt BG. The evolutionary history of methicillin-resistant Staphylococcus aureus (MRSA). Proc Natl Acad Sci USA. 2002; 99: 7687-92.

59. Sá-Leão R, Santos I, Dias D, Peres I, Barros R, Lencastre H. Detection of an archaic clone of Staphylococcus aureus with low-level resistance to methicillin in a pediatric hospital in Portugal and in international samples: relics of a formerly widely disseminated strain? JClin Micorbiol. 1999; 37: 191320.

60. Deshpande LM, Fritsche TR, Jones RN. Molecular epidemiology of selected multidrug-resistant bacteria: a global report from the SENTRY Antimicrobial Surveillance Program. Diagn Microbiol Infect Dis. 2004; 49: 231-6.

61. Gruteke P, Goessens W, Gils J, Peerbooms N, Lemmens-den Toom, M Santen-Verheuvel, et al. Patterns of resistance associated with integrons, the extended-spectrum lactamase SHV-5 gene, and a multidrug efflux pump of Klebsiella pneumoniae causing a nosocomial outbreak. JClin Microbiol. 2000; 41: 1161-6.

62. Martins-Loureiro M, Aguiar de Moraes B, Lorenzato-Furtado de Mendonça V, Rocha-Quadra MR. Epidemiología molecular de cepas de Klebsiella pneumoniae productoras de $\alpha$ lactamasas de espectro extendido aisladas de pacientes neonatos en una unidad de cuidados intensivos involucrados en casos de infección hospitalaria en Río de Janeiro. Brasil Rev Latinoam Microbiol. 2001; 43: 88-95. 